\title{
Molecular Genetics of Salt Tolerance in Tomato F2 Segregating Population with the Aid of RAPD Markers
}

\section{Vincent Ezin ${ }^{1,2}$, Tatsiana Dasenka1, Pelagie Bidossessi Agbobatinkpo², Adam Ahanchede², Avtar Krishan Handa ${ }^{1}$}

${ }^{1}$ Department of Horticulture and Landscape Architecture, Purdue University, West Lafayette, USA

${ }^{2}$ Faculty of Agriculture, University of Abomey-Calavi, Cotonou, Benin

Email: ishola.vincent@yahoo.com, awevincent@gmail.com

How to cite this paper: Ezin, V., Dasenka, T., Agbobatinkpo, P.B., Ahanchede, A. and Handa, A.K. (2018) Molecular Genetics of Salt Tolerance in Tomato F2 Segregating Population with the Aid of RAPD Markers. Agricultural Sciences, 9, 1553-1568. https://doi.org/10.4236/as.2018.912109

Received: October 15, 2018

Accepted: December 7, 2018

Published: December 10, 2018

Copyright (c) 2018 by authors and Scientific Research Publishing Inc. This work is licensed under the Creative Commons Attribution International License (CC BY 4.0).

http://creativecommons.org/licenses/by/4.0/

\begin{abstract}
Salt tolerance of segregating progenies of a cross between a domesticated salt sensitive tomato cultivar (CA4) and a natural salt-tolerant wild-type tomato species (LA1606) was characterized. The $\mathrm{F}_{1}$ plants from this cross were selfed and $120 \mathrm{~F}_{2}$ segregating progenies from the resulting population along with parental CA4 and LA1606 plants were evaluated for salt tolerance. These plants were irrigated everyday with $185 \mathrm{mM} \mathrm{NaCl}$ for 82 days and quantitative traits were quantified including number of flowers, fruit number, fruit weight, fruit length, fruit width, fruit set percentage, and total yield. The two parental lines were evaluated for the presence of 27 seven independent RAPD markers and 7 markers were found to be polymorphic for the two genotypes. Bulk Segregant (BSA) analyses consisting of pooling 10 "most tolerant" and 10 "most sensitive" F2 segregating plants showed association of two RAPD polymorphic markers with higher salt tolerance. Two DNA markers that exhibit co-segregation with salt tolerance were identified and characterized. RAPD marker OPX-17 and MRTOMR-022 exhibited 2 positive molecule markers (polymorphism) which were found only in the resistant parent (LA1606) and resistant F2 bulk.
\end{abstract}

\section{Keywords}

Tomato, Segregating Lines, Molecular Markers, Phenotypic Traits

\section{Introduction}

Salinity is an important environmental factor affecting the tomato production in many part of the world, especially coastal regions [1] [2]. Apart from naturally 
occurring salinization, poor irrigation practices also contribute to soil salinity [3] [4] [5]. Osmotic and ionic stresses are key issues due to the excess of $\mathrm{Na}+$ ions, which hinder the growth, development and the productivity of most plants [6] [7] [8]. Many effects are observed during salinity stress: reduction in growth rate, in cell elongation and cell division, in lateral shoot formation and the earlier flowering with reduced clusters, fruit set percentage and yield [4] [5] [9] [10].

Attempts to develop tomato cultivars resistant to salinity via breeding have met with limited success and tomato cultivar tolerant to even moderate salinity has not yet been released to farmers [6] [11]. Enhanced tolerance to salinity in tomato via genetic engineering has been reported by several investigators [12] [13] [14] [15] [16]. These attempts include both single gene transformation and pyramiding of genes associated with enhanced salinity tolerance [17]-[23]. These genes include Est-3, Prx-7, and 6Pgdh-2 and Pgi-1 [17], BADH [24] [25] LeNHX2 [26] (Rodriguez-Rosales et al., 2008), SlSOS1, SISOS2, SISOS3, LeNHX1, LeNHX3 [27], SlAIM1 [28], osmotin [29], SINAC1 and SINAM1 [30], SlGME1 and SlGME2 [31], SlNAC4 [32], ShDHN, a dehydrin gene [23] and SpRing [33]. However, in spite of ample efforts to introduce salinity tolerance via the genetic engineering, a salt tolerant variety has not yet been released for any crop plant including tomato. The identification and introgression of beneficial genes from wild germplasm into tomato crop is of paramount importance for its improvement and would likely help develop salt tolerant tomato germplasm [34].

Natural variation has been suggested to be a great source of desirable quantitative traits including salinity tolerance in crop plants [35] [36] [37] [38]. In this respect significant progress has been made in identifying and mapping the quantitative trait loci (QTLs) associated with crop performance and yield including salinity tolerance [19] [39]-[44]. Emerging genomic technologies, especially availability of genome sequences for many crop species, have significantly speed up progress in identifying genes encoded by the selected QTLs. The other methods that have made possible the identification of molecular marker responsible for various traits include isozyme analysis, restriction fragment length polymorphisms (RFLP), and random amplified polymorphic DNA (RAPD), transcriptome, proteome and metabolome [34] [39] [45] [46] [47] [48]. RAPD that utilizes 10 base pair random primers has provided a method to identify DNA regions altered during the adaptation of species to various environmental cues [49] [50]. The polymorphism among the genomes of related species identified by RAPD can be further defined by sequencing of altered genomic region and available genome sequence [51]. Bioinformatics analyses of proteins encoded by genes in the cloned variable region along with reverse genetics have helped to understand the genetic bases of improved environmental adaptability [51]. The straightforwardness and simplicity of the RAPD technique make it ideal for genetic mapping, plant breeding, and DNA fingerprinting, with particular utility in the field of population genetics [49] [50] [52]. 
We have characterized a domesticated salt sensitive tomato cultivar (CA4) and a natural salt-tolerant variant of tomato species (LA1606) and their genetic cross to evaluate the molecular bases of salt tolerance in the resistant tomato variety. Based on phenotypic analyses of growth and development related traits among the $120 \mathrm{~F}_{2}$ segregating population of cross between tolerant and sensitive species. We further report identification and molecular characterization of two DNA markers that exhibit co-segregation with salt tolerance.

\section{Materials and Methods}

\subsection{Experimental Site}

The experiment was conducted on Tomato (Lycopersicon esculentum Mill.) at Purdue University, West Lafayette, USA.

\subsection{Plant Materials and Growing Conditions}

The seed materials included two parental lines, salt-tolerant (LA1606, Solanum pimpinellifolium) and salt sensitive (CA4, Solanum lycopersicum), and $\mathrm{F}_{2}$ populations. The seeds of tomato sown in June 8, 2012 in trays filled with peat moss. The trays were kept in greenhouse and watered daily. On July $3^{\text {rd }}, 2012,120 \mathrm{~F}_{2}$ plants and 8 parental line plants were transplanted into plastic pots $(20.5 \mathrm{~cm}$ diameter and $16.5 \mathrm{~cm}$ height) filled with $7 \mathrm{~kg}$ of soil. Plants in the plastic pots were daily irrigated with $185 \mathrm{mM} \mathrm{NaCl}$ treatment until harvest. Controls parental lines were treated with water. Plants were grown in greenhouse and the average day/night temperatures for June, July, August, September and October was $32^{\circ} \mathrm{C}$. Branches were removed from tomato plants as they were put in place. Pesticide was sprayed weekly to avoid diseases and insects infestation.

\subsection{Phenotyping: Trait Measurement}

For each F2 plant and parental lines, number of leaves, days to maturity, fruit number, fruit length, width, and weight and total yield were measured as follows:

1) Plant height: The height (in $\mathrm{cm}$ ) of the plant at maturity from the base to the top most growing tip of the plant.

2) Flower number: The total number of flowers from clusters two to six on each plant tagged during anthesis. Consider the cluster which flowers first.

3) Days to maturity: The total number of days from sowing to at least one fruit ripens

4) Fruit number (I): The total number of fruits from clusters 1 to 8 on each plant

5) Fruit setting percentage: The total fruit number divided by the total flower number from clusters one to eight on each plant

6) Fruit length: Recorded (in $\mathrm{mm}$ ) from stem end to blossom end, to one decimal place, at maturity from clusters two to six on each plant

7) Fruit width: Recorded (in $\mathrm{mm}$ ) at the largest diameter of cross-sectioned fruits to one decimal place, at maturity from clusters two to six on each plant 
8) Fruit weight (I): The average fruit weight from clusters 1 to eight on each plant

10) Fruit number (II): The total number of fruits on each plant

11) Yield: The total fruit weight in grams of each plant

12) Fruit weight (II): The average fruit weight per plant

\subsection{Molecular Analysis}

\subsubsection{DNA Extraction}

Young leaf tissues were collected in eppendorfs from individual $F_{2}$ plants and parental lines and placed into a box of ice. In the laboratory young tomato leaves were immediately frozen in liquid nitrogen and ground with a sterilized pestle 4 - 5 times while keeping them frozen with liquid nitrogen to break cells and homogenize tissue. Extraction buffer containing $1 \mathrm{M}$ Tris- $\mathrm{Cl}$ ( $\mathrm{pH}$ 7.5), $1 \mathrm{M}$ $\mathrm{NaCl}, 2.5$ of $0.5 \mathrm{M}$ EDTA, and $0.25 \mathrm{~g}$ SDS was added to each tube and shake sticks in the tube to dissolve macerated tissues in buffer completely and vortex tubes for $5 \mathrm{~min}$. Mixed tubes was centrifuge at 12,000 rpm for $2 \mathrm{~min}$. $300 \mu \mathrm{l}$ of supernatant was taken out in a separate properly labeled tube and $300 \mu \mathrm{l}$ isopropanol was added in them. Tubes were carefully mixed by slowly inverting them 5 times and allowing them to rest for $2 \mathrm{~min}$. The mixed tubes were centrifuge at $12,000 \mathrm{rpm}$ for $5 \mathrm{~min}$. The supernatant was discarded by gently inverting tubes in the sink. Tubes were put in open and inverted position onto tissue paper for $15 \mathrm{~min}$. Next, $100 \mu \mathrm{l}$ of TE buffer ( $10 \mathrm{mM}$ Tris-Cl and $1 \mathrm{mM}$ EDTA was added to each tube.

\subsubsection{RAPD Analysis}

\section{Screening RAPD Markers}

A total of 27 10-mer primers were used to screen between the two parents to determine which primers could be used to identify genes responsible for salt tolerance. Markers that segregated between parent lines during the initial primer screening were then used to screen tolerant bulk and susceptible bulk samples. Amplification reactions were performed in $25 \mu \mathrm{l}$ reaction volumes containing 5 $\mu \mathrm{l}$ of $5 \mathrm{x}$ buffers, $2 \mu \mathrm{l}$ of $25 \mathrm{mM} \mathrm{MgCl}_{2}, 0.5 \mu \mathrm{l}$ of $10 \mathrm{mM} \mathrm{dNTP}, 1 \mu \mathrm{l}$ of $125 \mathrm{ng} / \mu \mathrm{l}$ primer and $0.5 \mu \mathrm{l}$ enzyme (Taq polymerase) and $14.5 \mu \mathrm{l}$ of $\mathrm{ddH}_{2} \mathrm{O}$. A drop of mineral oil was overlaid on the reaction mixture. DNA amplifications were performed in a thermal cycler (Eppendorf) using the following cycling condition: one cycle of $92^{\circ} \mathrm{C}$ for $3 \mathrm{~min} ; 45$ cycles of $92^{\circ} \mathrm{C}$ for $0.30 \mathrm{~min}, 42^{\circ} \mathrm{C}$ for $1 \mathrm{~min}$ and $72^{\circ} \mathrm{C}$ for $0.30 \mathrm{~min}$; one cycle of $72^{\circ} \mathrm{C}$ for $8 \mathrm{~min}$ followed by holding at $4^{\circ} \mathrm{C}$.

\section{Polymerase chain reaction}

The PCR reaction mixture was $5 \mu \mathrm{l}$ of $5 \mathrm{x}$ Buffer, $2 \mu \mathrm{l}$ of $25 \mathrm{mM} \mathrm{MgCl}_{2}, 0.5 \mu \mathrm{l}$ of $10 \mathrm{mM}$ dNTPs, $1 \mu \mathrm{l}$ of $125 \mathrm{ng} / \mu \mathrm{l}$ primer, $125 \mathrm{ng} / \mu \mathrm{l}$ (Taq DNA Polymerase), 2 $\mu \mathrm{l}$ of genomic DNA, and $14.5 \mu \mathrm{l}$ of $\mathrm{ddH}_{2} \mathrm{O}$. A drop of mineral oil was added to the mixture. An automatic thermal was programmed for $5 \mathrm{~min}$ at $94^{\circ} \mathrm{C}, 45$ cycles of $1 \mathrm{~min}$ at $94^{\circ} \mathrm{C}, 2 \mathrm{~min}$ at $44^{\circ} \mathrm{C}$ and $2 \mathrm{~min}$ at $72^{\circ} \mathrm{C}$ for each cycle, and a 
final extension step of $10 \mathrm{~min}$ at $72^{\circ} \mathrm{C}$. Reaction product was resolved on a $1 \%$ agarose gel.

\subsection{Bulked Segregant Analysis}

Bulked segregant analysis (BSA) was performed following the method of [53]. Two DNA bulks, called resistant bulk (RB) and susceptible bulk (SB) were prepared from F2 individuals. The RB consisted of 10 individuals with high value of total yield, high expression of fruit set percentage, high total weight from cluster 2 to 6 and SB contained 10 individuals with low value of total yield, low fruit set percentage, low total weight from cluster 2 to 6 . These two DNA bulks were prepared by pooling equal amounts of DNA $(20 \mu \mathrm{l})$ from each individual. PCR was run with polymorphic primers between parents on the bulks and parental DNA samples using the same reaction conditions as described above. PCR was repeated for at least two times for those primers that were polymorphic between bulks.

\subsubsection{Gel Electrophoresis}

Amplification products were analyzed by gel electrophoresis in Agarose (1\% $\mathrm{W} / \mathrm{V})$ gels containing ethidium bromide in $1 \mathrm{x}$ TBE buffer $(10.8 \mathrm{~g}$ Tris $\mathrm{HCl}, 5.5 \mathrm{~g}$ boric acid and $4 \mathrm{ml}$ of $0.5 \mathrm{mM}$ EDTA for 1 liter). Gels were filled by pippeting the primer samples directly into the wells. Once the gels were loaded the covers were replaced and connected to the power source. The voltage was set at 250 and the current $(\mathrm{I}=3 \mathrm{~A})$ was allowed to run for 1.5 hours.

The gel was placed onto an ultraviolet illuminator with light box and digital camera setup attached and photographed. The gels were disposed appropriately after photographing.

\subsubsection{Data Analysis}

The length of the marker was estimated based on DNA marker co-electrophoresed, in base pairs. A molecular weight base pair ladder was used to measure the size of the RAPD marker bands on the agarose gel.

\subsection{Linkage Analysis}

Band presence and absence of DNA was scored within the $F_{2}$ population and parents for marker analysis. In the initial analysis, RAPD bands was scored for presence 1 and absence 0 for each population to perform a data matrix. In subsequent analysis, the markers were scored as absent (0), polymorphic (1).

\section{Result}

\subsection{Phenotypic Characterization}

The loading plots of principle component 1 and 2 of the PCA results obtained from phenological, physiological and agronomical data of $120 \mathrm{~F} 2$ progenies under to $185 \mathrm{mM} \mathrm{NaCl}$ are presented in Figure 1. In the PCA both quantitative (A) 
and individuals (B) variables and histogram of eigenvalues (C) are represented. The principle component 1 (PC1) describes $37.56 \%$ of the original information and principal component 2 (PC2) describes $22.31 \%$. The cumulative percentage of PC1 and PC2 was 59.87\% which revealed high level of variation. The phenological, physiological and agronomical parameters recorded from the severe salinity were separated by PCA1 and PCA2. chlorophyll content, total yield/plant, Fruit weight I \&II, number of fruits from cluster 2 - 6, fruit set percentage, average fruit width and length were grouped together with positive loading on the right upper side of the biplot, indicating positive correlation among these parameters. total number of flowers, number of flowers from cluster 2 to 6 , number of red fruits and green (unripe) fruits were found on the right lower side of the biplot and while day to matrity was observed on the left lower portion of the biplot.

The first three principal components (PCs) were associated with eigenvalues $>1$, while the fourth was equal to 1 and the remaining nine were $<1$.

Figures 2(a)-(c) show the distribution of traits in F2 population. The number of leaves, leaf length and total yield demonstrated a diverse range of variations, typical of quantitative traits.

\subsection{Genetic Characterization}

\section{Bulk Segregant Analysis from the response of F2 plants to salt stress}

The $120 \mathrm{~F} 2$ plants subjected to $185 \mathrm{mM}$ of $\mathrm{NaCl}$ for 82 continuous days responded differently to salt stress. According to their reaction to the treatment two groups were observed. The first group stands for individual plants with best performance under high salt stress and the second one are individual plants affected by the deleterious effect of high salt treatment (Table 1). The most tolerant plants were number $65,9,24,40,10,108,1,6,35$ and 18 while the most susceptible plants were $94,112,37,119,17,47,59,100,4$ and 118 (Table 1). 10 plants from each extreme, according to the method of bulked segregant analysis, were selected to reduce the sample size while allowing for the rapid screening of polymorphic markers. The high values of traits represent the most tolerant plants and the lowest values represent for the susceptible plants.

Ten plants taken from the most tolerant formed the resistant bulk (RB) and 10 other plants from the most susceptible represent sensitive bulk (SB) (Table 1).

\subsection{Screening of RAPD Markers for Salt Tolerance}

A total of 38 RADP markers were screened with the two contrasting parental lines (Table 2). Seven primers were found polymorphic with the parents (Table 3). Percentage of polymorphism between parents ranged from 14 to 75 . The highest values of polymorphism were recorded with RAPD markers 15OPC-08 and 9OPA-19 (75\% and 71\%, respectively) while the lowest (Table 3) was recorded with RAPD marker OPAK-19 (14\%). Two markers were identified to be associated with genes of interest. 

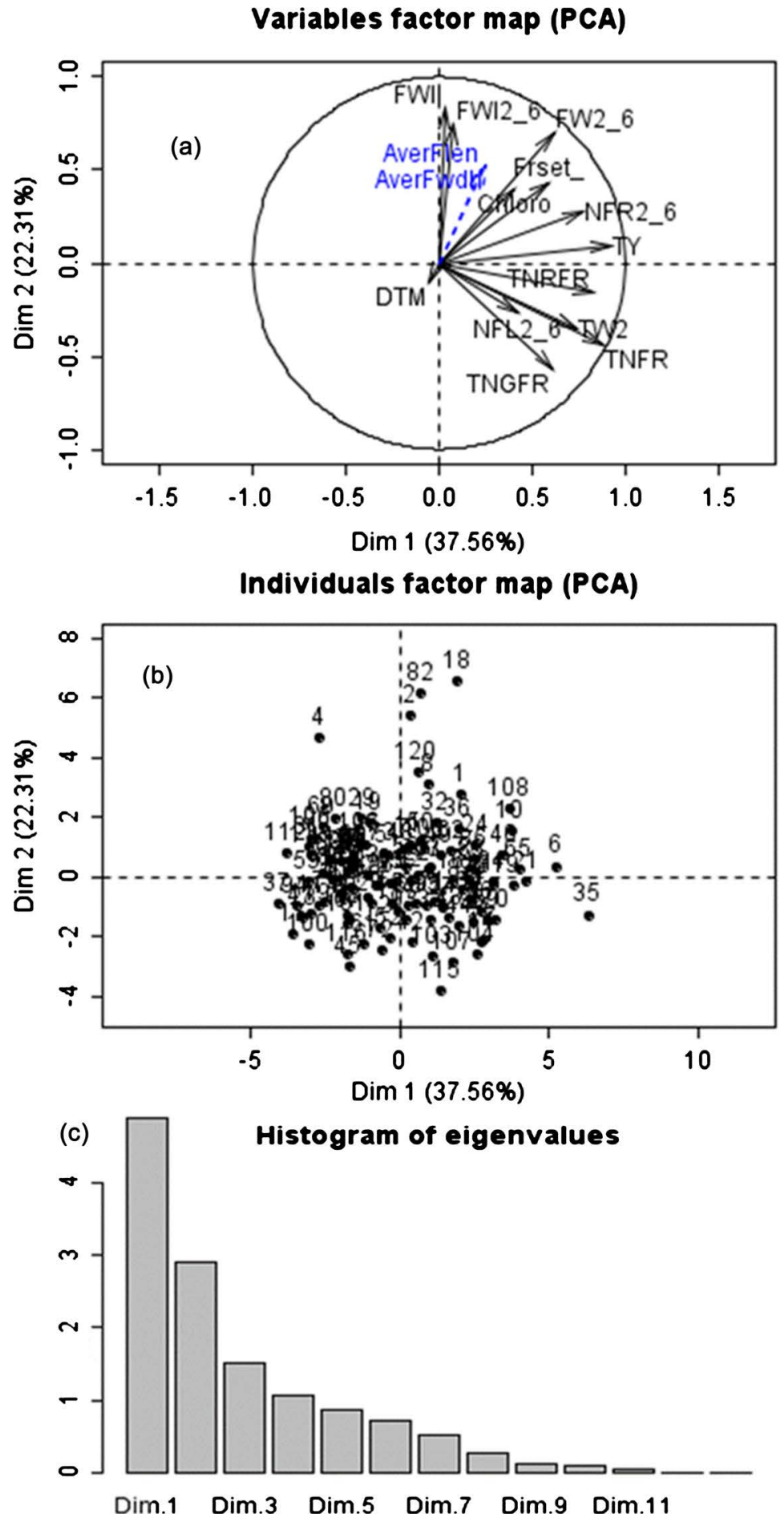

NFL2-6 = number of flowers from cluster 2 to 6 ; NFR2-6 = number of fruits from cluster 2 to 6; Fruit set $=$ fruit set percentage; TNFR $=$ total number of fruit per plant; TNRFR $=$ total number of red fruit per plant; TNGFR = total number of green fruit per plant; AverFlen = average fruit length from cluster 2 to 6 ; AvrFwdth = average fruit width from cluster 2 to 6 ; Ty $=$ total yield; FW2 $-6=$ total fruit weight from cluster 2 to 6 ; DTM = days to maturity; Chloro = chlorophyll content measured by SPAD 502. Number 1 to 120 are the plant number of plants in the F2 population

Figure 1. Principle components analysis (PCA) results obtained from phenological, physiological and agronomical data of 120 tomato F2 lines subjected to high salinity. 

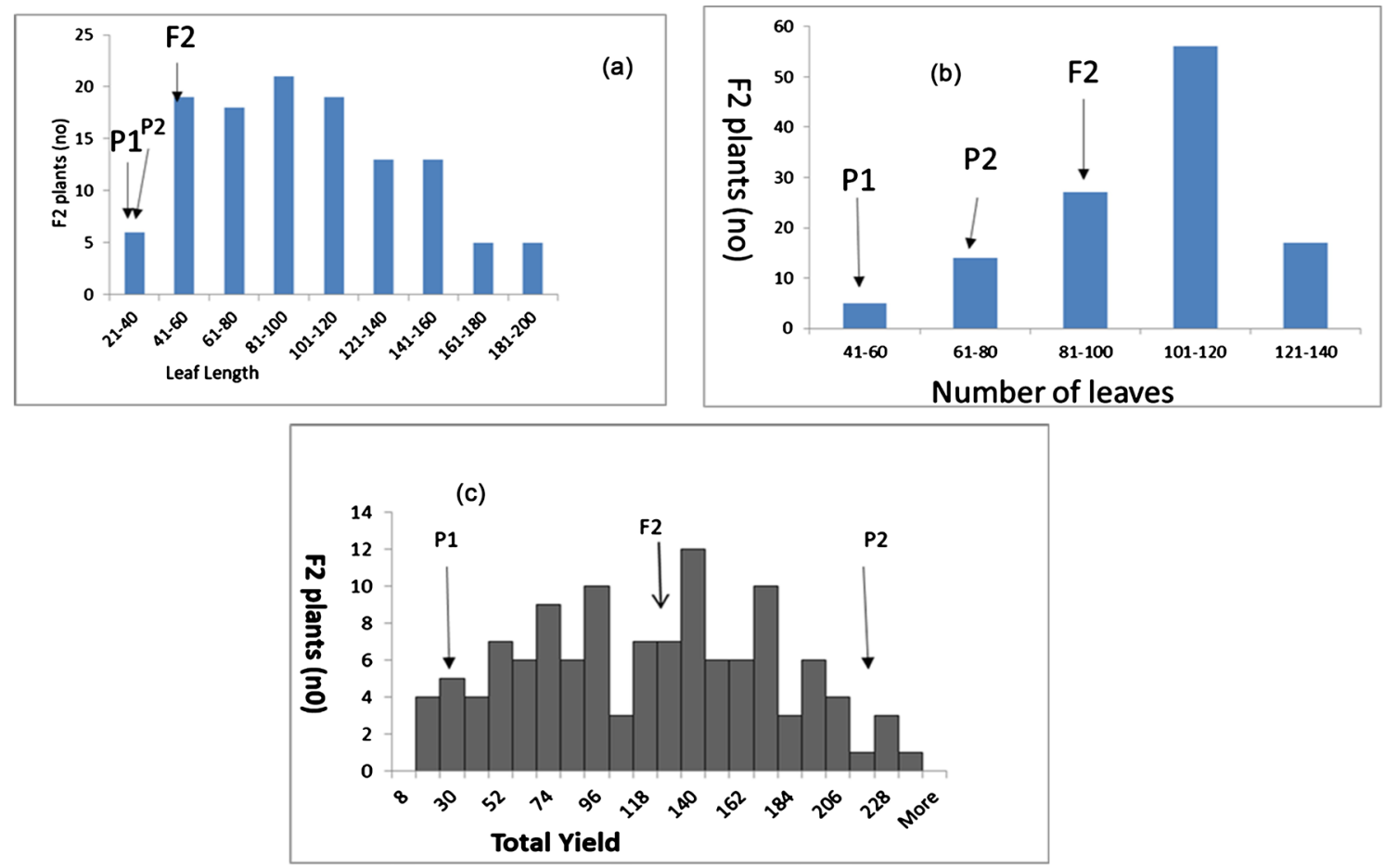

Figure 2. Frequency distribution of (a) leaf length, (b) Number of leaves and (c) total yield per plant, P1 is parent 1 (CA4 cultivar), $\mathrm{P} 2$ is parent 2 (LA1606) and F2 is second generation progeny obtained from self-pollination of F1 population

Table 1. The most tolerant and the most sensitive F2 plants based on salt tolerance related traits.

\begin{tabular}{|c|c|c|c|c|c|}
\hline & Plant no. & NFR & FRset\% & FW2-6 & TY \\
\hline \multirow{10}{*}{ Most tolerant } & 65 & 17 & 30.4 & 70.23 & 220.77 \\
\hline & 9 & 23 & 30.7 & 64.97 & 167.43 \\
\hline & 24 & 9 & 23.1 & 61.16 & 224.43 \\
\hline & 40 & 16 & 48.3 & 79.36 & 214.72 \\
\hline & 10 & 27 & 33.8 & 177.33 & 186.89 \\
\hline & 108 & 22 & 55 & 104.71 & 196.96 \\
\hline & 1 & 14 & 28.1 & 87.89 & 184.08 \\
\hline & 6 & 21 & 32.8 & 85.39 & 238.04 \\
\hline & 35 & 33 & 45.2 & 83.03 & 202.50 \\
\hline & 18 & 20 & 71.4 & 162.85 & 162.85 \\
\hline \multirow{10}{*}{ Most sensitive } & 94 & 2 & 4.8 & 1.16 & 8.39 \\
\hline & 112 & 1 & 0.5 & 1.12 & 13.41 \\
\hline & 37 & 1 & 2.3 & 3.58 & 9.32 \\
\hline & 119 & 2 & 4.3 & 4.88 & 28.39 \\
\hline & 17 & 2 & 5.3 & 1.57 & 28.21 \\
\hline & 47 & 2 & 6.9 & 2.42 & 30.68 \\
\hline & 59 & 5 & 9.6 & 12.89 & 19.52 \\
\hline & 100 & 2 & 4.3 & 2.54 & 36.96 \\
\hline & 4 & 4 & 12.1 & 36.21 & 36.21 \\
\hline & 118 & 10 & 37 & 23.73 & 27.6 \\
\hline
\end{tabular}

NFR: number of fruit, FRset\%: fruit set percentage, FW2-6: fruit weight from cluster 2 to 6, TY: total yield. 
Table 2. Sequence of the 38 RAPD primers used in this study.

\begin{tabular}{cccc}
\hline Name of the primer & $\begin{array}{c}\text { Sequence of primer } \\
(5 \rightarrow 3)\end{array}$ & Name of the primer & $\begin{array}{c}\text { Sequence of primer } \\
(5 \rightarrow 3)\end{array}$ \\
\hline OPX-02 & TTCCGCCACC & OPA-09 & GGGTAACGCC \\
17OPE-07 & AGATGCAGCC & OPC-08 & TGGACCGGTG \\
OPA-19 & CAAACGTCGG & OPX-14 & ACAGGTGCTG \\
OPAK-19 & TCGCAGCGAG & OPB-06 & TGCTCTGCCC \\
OPB-15 & GGAGGGTGTT & 15OPC-08 & TGGACCGGTG \\
OPC-18 & TGAGTGGGTG & 9OPA-19 & GACGCTGGGC \\
OPC-06 & GAACGGACTC & OPB-17 & AGGGAACGAG \\
OPAK-05 & GATGGCAGTC & 19OPI-09 & TCGAGAGCAG \\
OPA-04 & AATCGGTGTT & OPC-19 & GTTGCCAGCC \\
OPA-13 & CAGCACCCAC & OOPA-07 & GAAACGGGTG \\
OPX-08 & CAGGGGTGGA & OPB-05 & TGCGCCCTTC \\
OPX-17 & GACACGGACC & 2OPA-02 & TGCCGAGCTG \\
8 OPA-16 & AGCCAGCGAA & OPA-08 & GTGACGTAGG \\
7 OPA-11 & GGACTGGAG & MRTOMR-027 & ACCTGATGCA \\
MRTOMR-046 & CCATGCGCTA & Z13 & GACTAAGCCC \\
OPE 1 & CCCAAGGTCC & OPD 6 & ACCTGAACGG \\
OPU-03 & CTATGCCGAC & OPV-19 & GGGTGTGCAG \\
OPD 3 & AAGCGGCCTC & MRTOMR-117 & CCG AAC AAT C \\
\hline & GTCGCCGTCA & OPA 15 & TTCCGAACCC \\
\hline
\end{tabular}

Table 3. RAPD primers polymorphic between resistant and susceptible parents of tomato to salt tolerant.

\begin{tabular}{ccccccc}
\hline Primer & $\begin{array}{c}\text { Amplified } \\
\text { bands }\end{array}$ & $\begin{array}{c}\text { Band size (bp) } \\
\text { Max min }\end{array}$ & $\begin{array}{c}\text { Polymorphic } \\
\text { bands }\end{array}$ & \% polymorphic & Tm \\
\hline OPX-17 & 5 & 800 & 300 & 1 & 20 & 32 \\
MRTOMR-022 & 7 & 1517 & 300 & 2 & 29 & 32 \\
OPAK-19 & 7 & 1200 & 300 & 1 & 14 & 32 \\
OPX-14 & 5 & 1000 & 400 & 1 & 32 \\
OPX-08 & 3 & 1200 & 400 & 1 & 33 & 32 \\
9OPA-19 & 7 & 1000 & 300 & 5 & 35 & 32 \\
15OPC-08 & 4 & 1000 & 300 & 3 & 35 \\
\hline
\end{tabular}

Figure 3(a) shows the amplification pattern of RAPD marker OPB-05 linked to the susceptible allele. Lane $\mathrm{M}$ is $100 \mathrm{bp}$ molecule-weight ladders, lane SP is the susceptible parent, lane RP is the resistant parent. The two arrows in Figure 3(a) reveal the susceptible and resistant alleles respectively. The allele associated with the susceptible parent corresponded to $1200 \mathrm{bp}$ while that of tolerance was $1100 \mathrm{bp}$. 


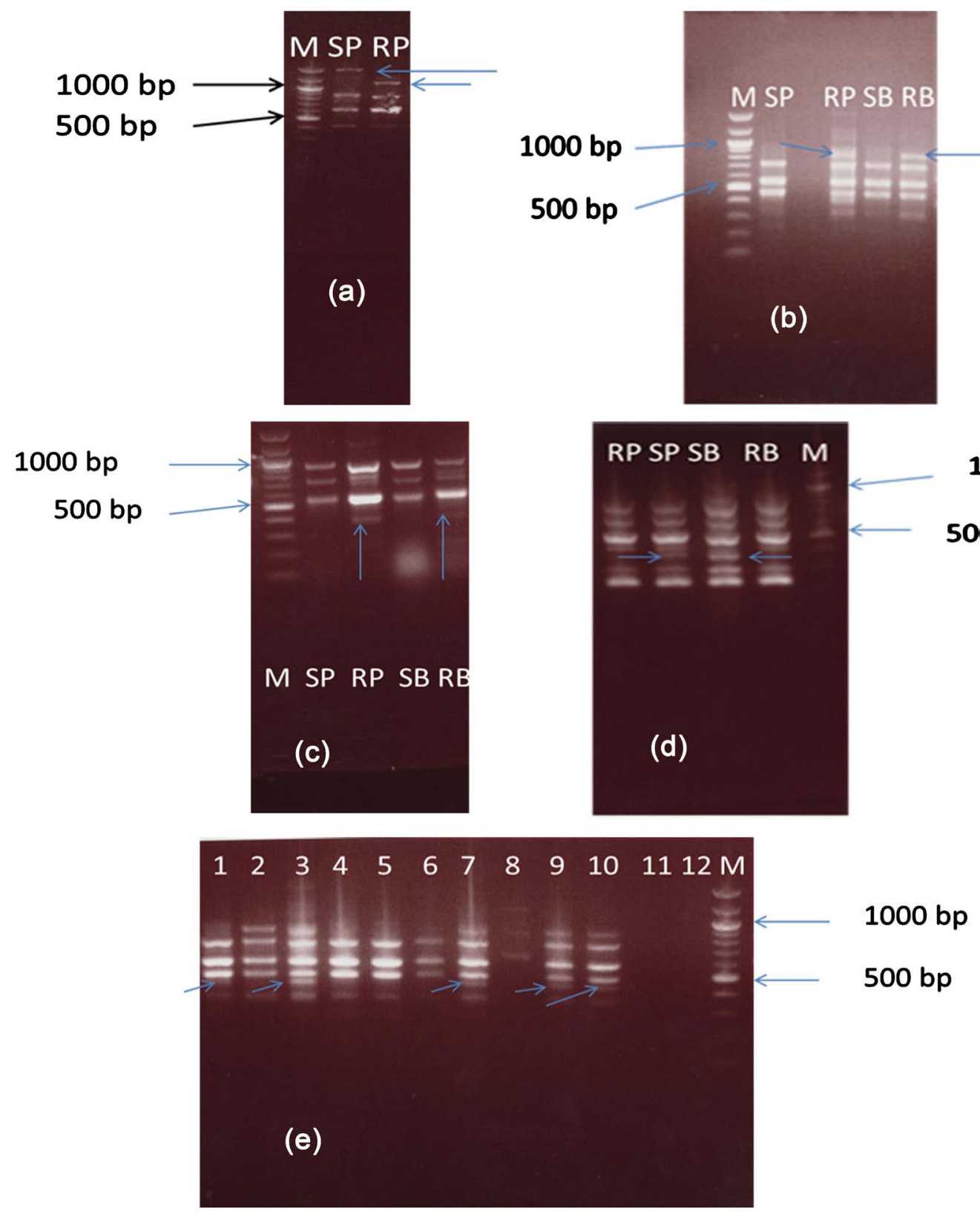

Figure 3. Amplification products of RAPD markers; (a) RAPD marker OPB 05 expressing polymorphism between susceptible parent (SP; the arrow indicates allele of susceptibility) and resistance parent (RP; the arrow indicates allele of resistance); (b): RAPD marker MRTOMR-022 expressing polymorphism between susceptible bulk (SB), resistant bulk (RB; the arrow indicates allele of resistance from the bulk DNA), susceptible parent (SP) and resistance parent (RP; the arrow indicates allele of resistance from the resistant parent) and molecular marker (M); (c): RAPD marker OPX 17 expressing polymorphism between resistant bulk (RB; the arrow indicates allele of resistance from the bulk DNA) and susceptible bulk (SB) from 6 resistant individuals and 6 susceptible individuals along with susceptible parent (SP) and resistant parent (RP; the arrow indicates allele of resistance from the resistant parent); (d): Bulk segregant analysis from F2 population derived from the cross between LA1606 (RP) and CA4 (SP; the arrow indicates allele of susceptibility from the susceptible parent). Amplification products were generated from genomic of 10 salt tolerant bulks (high) and 10 sensitive bulks (low; the arrow indicates allele of susceptibility from the bulk DNA) with MRTOM-022 RAPD primer; and (e): RAPD marker MRTOM-022 expressing polymorphism between contrasting parents, resistant bulk (RB) and susceptible bulk (SB) from 5 resistant individuals and 5 susceptible individuals along with susceptible parent (SP) and resistant parent (RP). M is the molecular ladder used with $500 \mathrm{bp}$ the low value of molecular size and $1000 \mathrm{bp}$ the high value of molecular size. 
Figure $3(\mathrm{~b})$ is the electrophoresis pattern of DNA fragments generated by RAPD marker MRTOMR-022. The polymorphic bands linked to resistance gene between resistant parent (RP) and resistant bulk is indicated by arrows. RAPD marker MRTOMR-022 exhibited two positive polymorphic bands which were found only in the tolerant parent and tolerant F2 bulk with molecule size of 900 bp while there were absent in the susceptible parent and sensitive F2 bulk.

The amplification pattern using RAPD primer OPX-17 is showed in Figure $3(c)$. RAPD primer OPX-17 produced amplification present in the resistant parent and tolerant F2 bulk. This polymorphic band was observed neither in the susceptible parent nor in the susceptible F2 bulk. This band generated by RAPD primer OPX-17 had $400 \mathrm{bp}$. The 2 polymorphic bands revealed in tolerant parent and tolerant F2 bulk by RAPD marker MRTOMR-022 and RAPD primer OPX-17 with different base pairs demonstrate that the gene responsible for salt tolerance is not monogenic but rather polygenic.

Figure 3(d) illustrates RAPD banding patterns between tolerant and susceptible parent and tolerant and sensitive F2 bulks. The alleles linked to the susceptibility in sensitive parent and sensitive F2 bulk is indicated with arrows. These negative polymorphic bands were only present in the sensitive parent and sensitive F2 bulk with a molecule size of approximately $300 \mathrm{bp}$. They were not observed in the tolerant parent and tolerant F2 bulk.

Figure 3(e) exhibits the polymorphic band patterns of RAPD MRTOMR--022 from susceptible parent, tolerant parent susceptive bulk, resistant bulk and 5 susceptible individual and 5 resistant individual F2. The arrows show the alleles responsible for susceptibility in sensitive parent, bulk and individuals. This band generated by RAPD marker MRTOMR-022 possesses $400 \mathrm{bp}$.

\section{Discussion}

Our aim was to find RAPD markers linked to the genes responsible for salt tolerance in tomato in order to use them in marker assisted breeding programs. [53] reported that bulk segregant analysis provides a rapid, technically simple alternative for identifying markers linked to specific genes, but the only prerequisite is the existence of a population resulting from a cross that segregates for the gene of interest and the success of the approach will depend on the genetic divergence between the parents in the target region. In the present study RAPD marker OPX-17 and MRTOMR-022 exhibited 2 positive molecule markers (polymorphism) which were found only in the resistant parent (LA1606) and resistant F2 bulk with molecular size of 400 bp for RAPD marker OPX-17 and 900 bp for RAPD marker MRTOMR-022, while there were absent in the sensitive parent (CA4) and susceptible F2 bulk. Similar results were found by [34] who identified hundreds of thousands of polymorphic positions that make distinction between cultivated tomato and wild relative species. On the other hand, RAPD marker MRTOMR-022 exhibited a negative molecule marker which was found only in the sensitive parent (CA4) and sensitive F2 Bulk with molecule size of 
400 bp (Figure 3(e)). We identified two potential and positive RAPD markers associated with salt tolerance and could be regarded as trustworthy markers for salt tolerance in tomato. Our results are consistent with those of [53] [54] [55] [56] [57] who reported that RAPD analysis combined with BSA has been used to screen for markers linked to genes of interest. Our results suggest that targeting OPX-17 and MRTOMR-022 markers for the high yield trait would be an effective way to improve tomato production under salt stress. Moreover, BSA has been intensively used in a number of crops including tomato species subjected to various environmental stresses to tag quantitative traits. However, because of low reproducibility of RAPD, these two positive RAPD primers can be converted to SCAR or CAPS which can be applied as a single marker.

[53] reported that for a dominant RAPD marker segregating in an F2 population, the probability of a pool of $\mathrm{n}$ individuals having a band and a second pool equal size not having a band is $2(1 / 4)^{\mathrm{n}}\left[1-(1 / 4)^{\mathrm{n}}\right]$ when the locus is unlinked to the target gene. From this, they concluded that a few individuals per bulk are enough to identify the linked markers. In the present study, we used 10 individuals out of a120 segregating F2 population studied and based on Michelmore et al. formular, the porpostion of false positive is $2 \times 10^{-6}$ which is very low. [53] demonstrated that even when many loci are screened, the chances of detecting an unlinked locus are very small; however, when smaller pools or bulks are utilized the frequency of false positives will increase. Therefore, as the linkage of all polymorphisms is confirmed by analysis of a segregating population, bulked segregant analysis with only reasonable numbers of individuals in both pools will provide great enrichment for markers linked to target loci.

\section{Conclusion}

The screening of salt tolerance markers from DNA parents and bulks is positively linked to genes of interest related to salt tolerance. Thus, RAPD marker OPX-17 and MRTOMR-022 exhibited 2 positive molecule markers (polymorphism) which were found only in the resistant parent (LA1606) and resistant F2 bulk. RAPD markers combined with BSA provided rapid approach for screening F2 segregating population.

\section{Acknowledgements}

The authors would like to acknowledge the financial support from Purdue University and the laboratory of Professor Handa where the work was carried out.

\section{Conflicts of Interest}

The authors declare no conflicts of interest regarding the publication of this paper.

\section{References}

[1] FAO (2004) Impact of Climate Change on Agriculture in Asia and the Pacific. 27 th FAO Regional Conference for Asia and the Pacific, Beijing, 17-21 May 2004, 1-94. 
[2] Uddin, M.S., Khan, MS.I., Talukdar, M.M.R., Hossain, M.I. and Ullah, MH (2011) Climate Change and Salinity in Bangladesh: Constraints and Management Strategy for Production. Rajshahi University Journal of Environmental Science, 1, 13-20.

[3] Parida, A.K. and Das, A.B. (2005) Salt Tolerance and Salinity Effects on Plants: A Review. Ecotoxicology and Environmental Safety, 60, 324-349.

https://doi.org/10.1016/j.ecoenv.2004.06.010

[4] Tuteja, N. (2007) Mechanisms of High Salinity Tolerance in Plants. Osmosensing and Osmosignaling. Elsevier Academic Press Inc., San Diego, 419-436. https://doi.org/10.1016/S0076-6879(07)28024-3

[5] Jawell, M.C., Campbell, B.C. and Godwin, I.D. (2010) Transgenic Plants for Abiotic Stress Resistance. In: Kole, C., Michler, C., Abbot, A.G. and Hall, T.C., Eds., Transgenic Crop Plants, 67-132. https://doi.org/10.1007/978-3-642-04812-8_2

[6] Foolad, M.R. (2004) Recent Advances of Salt Tolerance in Tomato. Plant Cell Tissue and Organ Culture, 76, 101-119. https://doi.org/10.1023/B:TICU.0000007308.47608.88

[7] Flowers, T.J. (2004) Improving Crop Salt Tolerance. Journal Experimental Botany, 55, 307-319. https://doi.org/10.1093/jxb/erh003

[8] Zhang, J.L., Flowers, T.J. and Wang, S.M. (2010) Mechanisms of Sodium Uptake by Roots of Higher Plants. Plant Soil, 326, 45-60. https://doi.org/10.1007/s11104-009-0076-0

[9] Munns, R. and Tester, M. (2008) Mechanisms of Salt Tolerance. Annual Review of Plant Biology, 59, 651-681. https://doi.org/10.1146/annurev.arplant.59.032607.092911

[10] Ezin, V., De la Pena, R. and Ahanchede, A. (2010) Physiological and Agronomical Criteria for Screening Tomato Genotypes for Tolerance to Salinity. Electronic Journal of Environmental, Agricultural and Food Chemistry, 9, 1641-1656.

[11] Ghassemi, F., Jakeman, A.J. and Nix, H.A. (1995) Salinisation of Land and Water Resources: Human Causes, Extent, Management and Case Studies. Canberra, Australia, The Australian National University, Wallingford, Oxon, UK: CAB International, Wallingford, England, p. 526.

[12] Foolad, M.R. and Jones, R.A. (1991) Genetic Analysis of Salt Tolerance during Germination in Lycopersicon. Theoretical and Applied Genetics, 81, 321-326.

[13] Foolad, M.R. and Jones, R.A. (1992) Parent-Offspring Regression Estimates of Heritability for Salt Tolerance during Germination in Tomato. Crop Science, 32, 439-442. https://doi.org/10.2135/cropsci1992.0011183X003200020031x

[14] Monforte, A.J., Asíns, M.J. and Carbonell, E.A. (1996) Salt tolerance in Lycopersicon Species. IV. Efficiency of Marker-Assisted Selection for Salt Tolerance Improvement. Theoretical and Applied Genetics, 93, 765-772.

https://doi.org/10.1007/BF00224074

[15] Cuartero, J., Bolarín, M.C., Asíns, M.J. and Moreno, V. (2006) Increasing Salt Tolerance in the Tomato. Journal of Experimental Botany, 57, 1045-1058. https://doi.org/10.1093/jxb/erj102

[16] Ouyang, B., Yang, T., Li, H., Zhang, L., Zhang, Y., Zhang, J., Fei, Z. and Ye, Z. (2007) Identification of Early Salt Stress Response Genes in Tomato Root by Suppression Subtractive Hybridization and Microarray Analysis. Journal of Experimental Botany, 58, 507-520. https://doi.org/10.1093/jxb/erl258

[17] Foolad, M.R. and Jones, R.A. (1993) Mapping Salt-Tolerance Genes in Tomato (Lycopersicon esculentum) Using Trait-Based Marker Analysis. Theoretical and 
Applied Genetics, 87, 184-192. https://doi.org/10.1007/BF00223763

[18] Breto, M.P., Asins, M.J. and Carbonell, E.A. (1994) Salt Tolerance in Lycopersicon Species III. Dectection of Quantitative Trait Loci by Means of Molecular Markers. Theoretical and Applied Genetics, 88, 395-4001.

https://doi.org/10.1007/BF00223650

[19] Foolad, M.R., Lin, G.Y. and Chen, F.Q. (1999) Comparison of QTLs for Seed Germination under Non-Stress, Cold Stress and Salt Stress in Tomato. Plant Breeding, 118, 167-173. https://doi.org/10.1046/j.1439-0523.1999.118002167.x

[20] Yeo, A.R., Koyama, M.L., Chinta, S. and Flowers, T. (2000) Salt Tolerance at the Whole Plant Level. In: Cherry, J.H., Ed., Plant Tolerance to Abiotic Stresses in Agriculture: Role of Genetic Engineering, Vol. 3, Kluwer, 107-123. https://doi.org/10.1007/978-94-011-4323-3_8

[21] Quesada, V., Garcia-Martinez, S., Piqueras, P., Ponce, M.R. and Micol, J.L. (2002) Genetic Architecture of $\mathrm{NaCl}$ Tolerance in Arabidopsis. Plant Physiology, 130, 951-963. https://doi.org/10.1104/pp.006536

[22] Feng, H.L., Ma, N.N., Meng, X., Zhang, S., Wang, J.R., Chai, S. and Meng, Q.W. (2013) A Novel Tomato MYC-Type ICE1-Like Transcription Factor, SlICE1a, Confers Cold, Osmotic and Salt Tolerance in Transgenic Tobacco. Plant Physiology and Biochemistry, 73, 309-320. https://doi.org/10.1016/j.plaphy.2013.09.014

[23] Liu, H., Yu, C., Li, H., Ouyang, B., Wang, T., Zhang, J., Wang, X. and Ye, Z. (2015) Overexpression of ShDHN, a Dehydrin Gene from Solanum habrochaites Enhances Tolerance to Multiple Abiotic Stresses in Tomato. Plant Science, 231, 198-211. https://doi.org/10.1016/j.plantsci.2014.12.006

[24] Xiao, G., Zhang, G.Y., Liu, F.H., Wang, J., Chen, S.Y., Li, C. and Geng, H.Z. (1995) Study on BADH Gene from Atriplex hortensis L. Chinese Science Bulletin, 40, 741-745.

[25] Jia, G.X., Zhu, Z.Q., Chang, F.Q. and Li, Y.X. (2002) Transformation of Tomato with the BADH Gene from Atriplex Improves Salt Tolerance. Plant Cell Reports, 21, 141-146. https://doi.org/10.1007/s00299-002-0489-1

[26] Rodriguez-Rosales, M.P., Jiang, X., Gálvez, F.J., Aranda, M.N., Cubero, B. and Venema, K. (2008) Overexpression of the Tomato K+/H+ Antiporter LeNHX2 Confers Salt Tolerance by Improving Potassium Compartmentalization. New Phytologist, 179, 366-377. https://doi.org/10.1111/j.1469-8137.2008.02461.x

[27] Villalta, I., Reina-Sánchez, A., Bolarín, M.C., Cuartero, J., Belver, A., Venema, K., Carbonell, E.A. and Asins, M.J. (2008) Genetic Analysis of $\mathrm{Na}(+)$ and $\mathrm{K}(+)$ Concentrations in Leaf and Stem as Physiological Components of Salt Tolerance in Tomato. Theoretical and Applied Genetics, 116, 869-880. https://doi.org/10.1007/s00122-008-0720-8

[28] Abuqamar, S., Luo, H., Laluk, K., Mickelbart, M.V. and Mengiste, T. (2009) Crosstalk between Biotic and Abiotic Stress Responses in Tomato Is Mediated by the AIM1 Transcription Factor. The Plant Journal, 58, 347-360. https://doi.org/10.1111/j.1365-313X.2008.03783.x

[29] Goel, D., Singh, A.K., Yadav, V., Babbar, S.B. and Bansal, K.C. (2010) Overexpression of Osmotin Gene Confers Tolerance to Salt and Drought Stresses in Transgenic Tomato (Solanum lycopersicum L.). Protoplasma, 245, 133-141. https://doi.org/10.1007/s00709-010-0158-0

[30] Yang, R., Deng, C., Ouyang, B. and Ye, Z. (2011) Molecular Analysis of Two Salt-Responsive NAC-Family Genes and Their Expression Analysis in Tomato. Molecular Biology Reports, 38, 857-863. https://doi.org/10.1007/s11033-010-0177-0 
[31] Zhang, C., Liu, J., Zhang, Y., Cai, X., Gong, P., Zhang, J., Wang, T., Li, H. and Ye, Z. (2011) Overexpression of SlGMEs Leads to Ascorbate Accumulation with Enhanced Oxidative Stress, Cold, and Salt Tolerance in Tomato. Plant Cell Reports, 30, 389-398. https://doi.org/10.1007/s00299-010-0939-0

[32] Zhu, M., Chen, G., Zhang, J., Zhang, Y., Xie, Q., Zhao, Z. and Pan-Hu, Z. (2014) The Abiotic Stress-Responsive NAC-Type Transcription Factor SINAC4 Regulates Salt and Drought Tolerance and Stress-Related Genes in Tomato (Solanum lycopersicum). Plant Cell Reports, 33, 1851-1863.

https://doi.org/10.1007/s00299-014-1662-z

[33] Qi, S., Lin, Q., Zhu, H., Gao, F., Zhang, W. and Hua, X. (2016) The RING Finger E3 Ligase Spring Is a Positive Regulator of Salt Stress Signaling in Salt-Tolerant Wild Tomato Species. Plant and Cell Physiology, 57, 528-539. https://doi.org/10.1093/pcp/pcw006

[34] Koenig, D., Jiménez-Gómez, J.M., Kimura, S., Fulop, D., Chitwood, D.H., Headland, L.R., Kumar, R., Covington, M.F., Upendra Devisetty, K., Tat, A.V., Tohge, T., Bolger, A., Schneeberger, K., Ossowski, S., Lanz, C., Xiong, G., Taylor-Teeples, M., Brady, S.M., Pauly, M., Weigel, D., Usadel, B., Fernie, A.R., Peng, J., Sinha, N.R. and Maloo, J.N. (2013) Comparative Transcriptomics Reveals Patterns of Selection in Domesticated and Wild Tomato. PNAS Early Edition, 1-8.

http://www.pnas.org/cgi/doi/10.1073/pnas.1309606110 https://doi.org/10.1073/pnas.1309606110

[35] Bohnert, H.J., Nelson, D.E. and Jensen, R.G. (1995) Adaptation to Environmental Stresses. The Plant Cell, 7, 1099-1111. https://doi.org/10.1105/tpc.7.7.1099

[36] Foster, B.P., Ellis, R.P., Thomas, W.T.B., Newton, A.C., Tuberosa, R., This, D., El-Enein, R., Bahri, M.H. and Ben Salem, M. (2000) The Development and Application of Molecular Markers for Abiotic Stress Tolerance in Barley. Journal of Experimental Botany, 51, 19-27. https://doi.org/10.1093/jexbot/51.342.19

[37] Collins, N.C., Tardieu, F. and Tuberosa, R. (2008) Quantitative Trait Loci and Crop Performance under Abiotic Stress: Where Do We Stand? Plant Physiology, 147, 469-486. https://doi.org/10.1104/pp.108.118117

[38] Zhang, X., Lu, G., Long, W., Zou, X., Li, F. and Nishio, T. (2014) Recent Progress in Drought and Salt Tolerance Studies in Brassica Crops. Breeding Science, 64, 60-73. https://doi.org/10.1270/jsbbs.64.60

[39] Foolad, M.R. and Chen, F.Q. (1998) RAPD Markers Associated with Salt Tolerance in an Interspecific Cross of Tomato (Lycopersicon esculentum L. pennellii). Plant Cell Reports, 17, 306-312. https://doi.org/10.1007/s002990050398

[40] Chen, F.Q., Foolad, M.R., Hyman, J.R., Clair, D. and Beelman, R. (1999) Mapping of QTLs for Lycopene and Other Fruit Traits in a Lycopersicon esculentum L. pimpinellifolium Cross and Comparison of QTLs across Tomato Species. Molecular Breeding, 5, 283-299. https://doi.org/10.1023/A:1009656910457

[41] Foolad, M.R. (1999) Genetics of Salt Tolerance and Cold Tolerance in Tomato: Quantitative Analysis and QTL Mapping. Plant Biotechnology, 16, 55-64. https://doi.org/10.5511/plantbiotechnology.16.55

[42] Zhang, L., Lin, G.Y., Niño-Liu, D. and Foolad, M.R. (2003) Mapping QTLs Conferring Early Blight (Alternaria solani) Resistance in a Lycopersicon esculentum L. hirsutum Cross by Selective Genotyping. Molecular Breeding, 12, 3-19. https://doi.org/10.1023/A:1025434319940

[43] Foolad, M.R. (2007) Genome Mapping and Molecular Breeding of Tomato. International Journal of Plant Genomics, 2007, Article ID: 64358. 
https://doi.org/10.1155/2007/64358

[44] Ashrafi, H., Kinkade, M.P., Merk, H. and Foolad, M.R. (2012) Identification of Novel QTLs for Increased Lycopene Content and Other Fruit Quality Traits in a Tomato RIL Population. Molecular Breeding, 30, 549-567. https://doi.org/10.1007/s11032-011-9643-1

[45] Tanksley, S.D., Ganal, M.W., Prince, J.P., et al. (1992) High Density Molecular Linkage Maps of the Tomato and Potato Genomes. Genetics, 132, 1141-1160.

[46] Mulcahy, D.L., Cresti, M., Sansavini, S., Douglas, G.C., Linskens, H.F., Bergamini, G., Vignani, R. and Pancaldi, M. (1993) The Use of Random Amplified Polymorphic DNAs to Fingerprint Apple Genotypes. Scientia Horticultuae, 54, 89-96. https://doi.org/10.1016/0304-4238(93)90057-W

[47] Foolad, M.R., Chen, F.Q. and Lin, G.Y. (1998) RFLP Mapping of QTLs Conferring Salt Tolerance during Germination in an Interspecific Cross of Tomato. Theoretical and Applied Genetics, 97, 1133-1144. https://doi.org/10.1007/s001220051002

[48] Schaffer, A.A., Levin, I., Oguz, I., Petreikov, M., Cincarevsky, F., Yeselson, Y., Shen, S., Gilboa, N. and Bar, M. (2000) ADPglucose Pyrophosphorylase Activity and Starch Accumulation in Immature Tomato Fruit: The Effect of a Lycopersicon hirsutum-Derived Introgression Encoding for the Large Subunit. Plant Science, 152, 135-144. https://doi.org/10.1016/S0168-9452(99)00224-1

[49] Williams, J.G.K., Kubelik, A.R., Livak, K.J., Rafalski, J.A. and Tingey, S.V. (1990) DNA Polymorphisms Amplified by Arbitrary Primers Are Useful as Genetic Markers. Nucleic Acids Research, 18, 6531-6535. https://doi.org/10.1093/nar/18.22.6531

[50] Lynch, M. and Milligan, B.G. (1994) Analysis of Population Genetic Structure within RAPD Markers. Molecular Ecology, 3, 91-99. https://doi.org/10.1111/j.1365-294X.1994.tb00109.x

[51] Masojc, P. (2002) The Application of Molecular Markers in the Process of Selection. Cellular and Molecular Biology Letters, 7, 499-509.

[52] Mulcahy, D.L., Cresti, M., Linskens, H.F., Intrieri, C., Silverstoni, O., Vignani, R. and Pancaldi, M. (1995) DNA Fingerprinting of Italian Grape Varieties: A Test of Reliability in RAPDs. Advanced Horticultural Science, 9, 185-187.

[53] Michelmore, R.W., Paran, I. and Kesseli, V. (1991) Identification of Markers Linked to Disease-Resistance Genes by Bulked Segregant Analysis: A Rapid Method to Detect Markers in Specific Genomic Regions by Using Segregating Populations. Proceedings of the National Academy of Sciences of the United States, 88, 9828-9832. https://doi.org/10.1073/pnas.88.21.9828

[54] Chagué, V., Mercier, J.C. and Guenard, M. (1996) Identification of RAPD Markers Linked to a Locus Involved in Quantitative Resistance to TYLCV in Tomato by Bulked Segregant Analysis. Theoretical and Applied Genetics, 95, 671-677.

[55] Mackay, I.J. and Caligari, P.D.S. (2000) Efficiencies of F2 and Backcross Generations for Bulked Segregant Analysis Using Dominant Markers. Crop Science, 40, 626-630. https://doi.org/10.2135/cropsci2000.403626x

[56] Lin, K.H., Lo, H.F., Lee, S.P., Kuo, C.G., Chen, J.T. and Yeh, W.L. (2006) RAPD Markers for the Identification of Yield Traits in Tomatoes under Heat Stress via Bulked Segregant Analysis. Hereditas, 143, 142-154.

[57] Kamel, M.A., Soliman, S.S., Mandour, A.E. and Ahmed, M.S.S. (2010) Genetic Evaluation and Molecular Markers for Heat Tolerance in Tomato (Lycopersicon esculentum Mill.). Journal of American Science, 6, 364-374. 